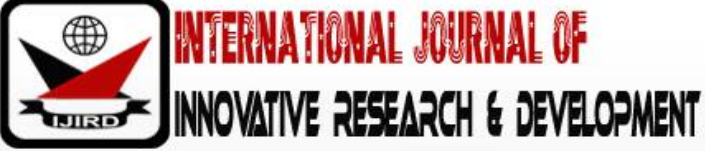

ISSN 2278 - 0211 (Online)

\section{Review on the Information Needs and Sources of Information for Agricultural Development in Developing Countries}

\author{
Abdu Rahman Baba Saje \\ Assistant Lecturer, Department of Gujba Agricultural Technology, \\ Yobe State College of Agriculture, Nigeria
}

\begin{abstract}
:
Agriculture can serve as an important engine for economic development in developing countries. Yet for decades the sector has not met the expectations of the population in developing countries compared to the developed countries. Limited access to agricultural information is one of the key factors that have narrowed agricultural development in the developing countries. In the recent past, there has been failure of agricultural service providers to meet the information needs of farmers in relation to agricultural inputs, agricultural technology, extension education, agricultural credit and agricultural marketing. The study also outlines the information needs of farmers and the sources of information. The finding shows that the information needs of the farmers can be grouped according to the grouping proposed for grouping the information needs of farmers. Furthermore, information needs of farmers through agricultural cycle can be categorised into know-how which includes what to plant and inputs such as seed varieties to use; market information such as the demand indicators, prices and logistical information; and the contextual information such as best agricultural practices and weather forecast. The findings also show that ICTs could have impact on the agricultural production, marketing, environment sustainability and adoption of new agricultural innovations and thus enhance livelihoods and food security.
\end{abstract}

Keywords: Agricultural development, developing countries, ICTs, information needs

\section{Introduction}

Several methods and sources could be used in collection of data and information in developing countries for agricultural and rural development. Both traditional and modern means of communication could be used. Farmers especially those in rural area, are known to have greater access to non-digital or traditional methods such as print, television, video, pictures, folklore, drama, focus group discussions, exhibitions, demonstrations and meetings than the digital or modern methods such as e-mail, World Wide Web (WWW), mobile phones and Geographical Information System (GIS). Figures 1 and 2 are examples of focus group discussion. Traditional ICTs are important because their presence indicates the ways in which digital could be cost effective, improve quality, value and benefits. It provides the baseline to compare the costs of non-digital ICTs vis-a-vis digital ones (USAID, 2003, FAO, 2000). In the agricultural sector, the means of communication sometimes depends on the country and the ministries involved. However, according to the International Institute for Communication and Development (IICD, 2006), the appropriate application of ICTs in agriculture requires the use of relevant combinations of modern and traditional ICTs. The methods of information transfer can be voice information delivery services using mobile phone or landline; dial-up and regular radio broadcasts; extension services based on mobile phone and database monitoring (FARA, 2004). This section seeks to find out the different methods and sources of information available for agricultural development.

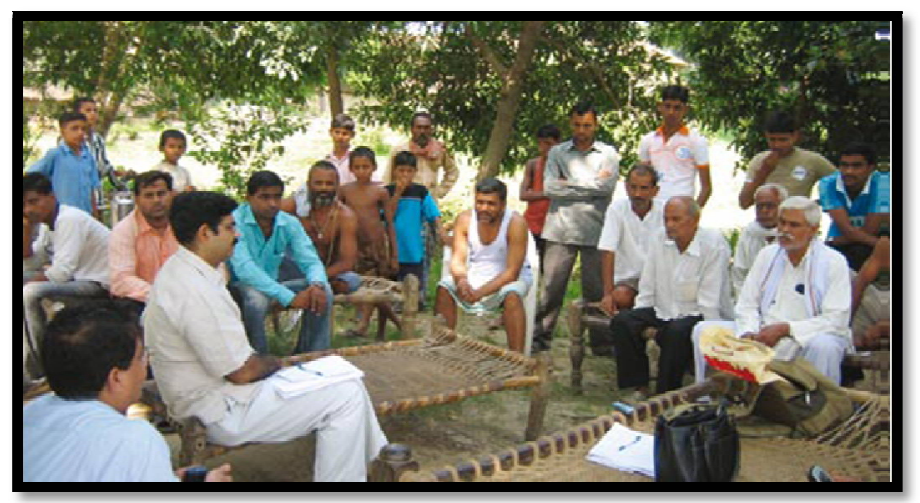

Figure 1: Focus Group Discussion with Farmers in India Source: Vodafone, (2009) 


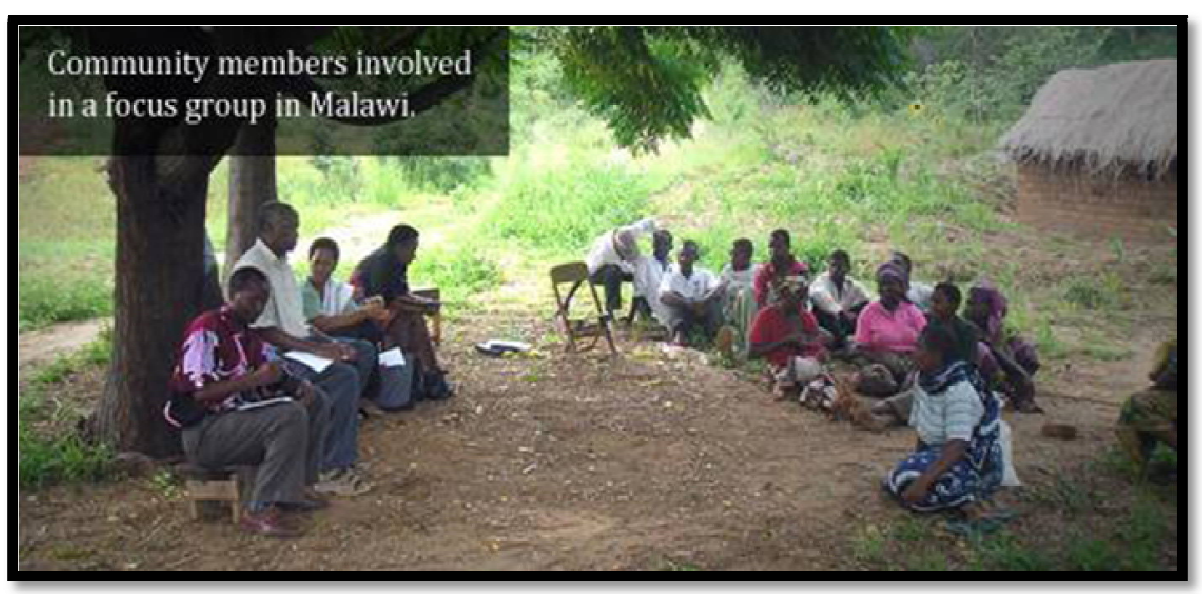

Figure 2: Focus Group Discussion in Malawi

Source: AFRRI, (2009)

\section{Information Sources for Agricultural Development}

The information sources such as radio, television, extension publications, farm newspapers, agricultural exhibitions and shows, training, church, government agencies, agricultural cooperatives, websites via VSAT broadband technology, practical education and consultation services such as extension advisory are available to farmers in SubSaharan Africa (Ha et al., 2008; Ekoja, 2003). The study by Kleih et al. (2004), interviewing 175 farmers and 56 traders in Lira Uganda, indicated that radio (75\%) is the main source of information among commodity traders. According to the study, $80 \%$ of traders owned a radio, $27 \%$ use payphone, and $21 \%$ have access to a mobile phone without owning and $20 \%$ own a mobile phone. The main sources of information for the farmers are from radio (88.6\%), friends, family and neighbours (81.7\%), local leaders and officials (62.5\%). 70\% of the farmers own a radio and radio is the main source for crop production information while friends, family and neighbours are the main sources of market information. Other sources of information for farmers according to the study include political gatherings and group meetings, church, traders, and newspapers. Mobile phone is found to be insignificant source of information among the farmers in Uganda (Kleih et al., 2004).

In addition, the study done by Mwakaje, (2010) in Tanzania studying 200 farmers indicated that market information sources are dominated by fellow farmers (88.8\%) relatives (56\%) and traders (37.5\%). However, only $23 \%$ of the farmers used ICT to access market information, but $72 \%$ of the farmers owned mobile phones and 169 had radio sets. According to the result, the number that used newspaper and primary cooperatives was insignificant.

The study done by Kari (2007), on availability and accessibility of ICT in Nigeria revealed that rural Nigerians have access to agricultural agents and rural health workers (24\%), radio (8\%), television (6\%), GSM services $(2.66 \%)$ and newspapers (2\%). Radio and Television are often seen as entertainment media rather than sources of information (Kari, 2007). In southern Africa, remote sensing data and geographical information systems are used to provide information to farmers on agricultural production conditions and food security (Weiss et al., 2000).

Moreover, according to AgREN (2000), the major sources of information and knowledge for smallholder farmers in Kenya are local means such as family, markets, neighbours and community based organisations. However, 40-70\% of the respondents reported extension as a relevant source of information, although the extension service was noted to not be satisfactory by the farmers and extension agents in the country.

The study done in Zambia by Kalusopa (2005) showed that farmers use non-governmental organisations such as farmers union (63.9\%); government extension agents (36.7\%); personal experience (46.8\%), and local groups (Indigenous Knowledge) (36.7\%) as the main sources of information for agricultural development. The results showed that the use of mobile phones and community radios as sources of information for small scale farmers in Zambia is still in its infancy due to poor telecommunication infrastructure, slow pace of private investment in the area and high tariffs. Table 1 summarizes the major sources of information for agricultural development.

\begin{tabular}{|c|c|c|}
\hline Information Sources & Study References & Country \\
\hline $\begin{array}{c}\text { Radio (80\% by farmers and 75\% by commodity traders), friends, family } \\
\text { and neighbour (81\%) and local leaders (62\%). }\end{array}$ & Keih et al. (2004) & Uganda \\
\hline Fellow farmers (88.8\%), relatives (56\%) and traders (37.5\%). & Mwakaje (2010) & Tanzania \\
\hline Radio (8\%), television (6\%), GSM service (2.66\%) and newspaper (2\%). & Kari, (2007) & Nigeria \\
\hline Remote sensing and GIS & Weiss et al. (2000) & Southern Africa \\
\hline Family, markets, neighbours and community based organisations. & AgREN (2000) & Kenya \\
\hline $\begin{array}{c}\text { Farmers union (63.9\%), government extension agents (36.7\%), personal } \\
\text { experience (46.8\%) and Indigenous Knowledge (36.7\%). }\end{array}$ & Kalusopa (2004) & Zambia \\
\hline $\begin{array}{c}\text { Radio, television, extension publications, farms newspapers and } \\
\text { agricultural exhibitions. }\end{array}$ & $\begin{array}{c}\text { Ha et al. (2008) and } \\
\text { Ekoja (2003) }\end{array}$ & $\begin{array}{c}\text { Sub-Saharan } \\
\text { Africa }\end{array}$ \\
\hline
\end{tabular}

Table 1: Summary of the Major Sources of Information for Agricultural Development 
From Table 1, the information sources for agricultural development in developing countries includes: radio, friends, family and neighbours, local leaders, fellow farmers, relatives, traders, television, GSM services, newspaper, remote sensing, GIS, markets, community based organisations, farmers' union, government extension agents, personal experience and indigenous knowledge. This finding supports IICD, (2006) proposal that the best sources of information combine both relevant traditional and modern ICTs. Table 2 and 3 show some of the ICT market information sources in developing countries and some organisations in developing countries in support of ICT-enabled agricultural information systems respectively.

\begin{tabular}{|c|c|c|}
\hline Projects & Countries & Websites \\
\hline Foodnet & $\begin{array}{c}\text { East and Central African } \\
\text { countries. }\end{array}$ & http:/ / www.foodnet.cgiar.org/ \\
\hline FAO Price tool & $\begin{array}{c}55 \text { developing countries } \\
\text { from Afghanistan to } \\
\text { Zimbabwe. }\end{array}$ & http:// www.fao.org/ giews/ pricetool2/ \\
\hline $\begin{array}{l}\text { FEWSNET (Famine Early Warning } \\
\text { Systems Network). }\end{array}$ & $\begin{array}{l}\text { West and East Africa } \\
\text { Countries }\end{array}$ & http:// www.fews.net/ Pages/ default.aspx \\
\hline Eastafa (East African Fish Auctions). & East African Countries & http:// www.eastafa.com/ \\
\hline $\begin{array}{l}\text { LINKS (Livestock Information } \\
\text { Network Knowledge System) }\end{array}$ & $\begin{array}{l}\text { For East African } \\
\text { Countries }\end{array}$ & http:/ / lmistz.net/ Pages/ Public/ Home.aspx \\
\hline $\begin{array}{c}\text { GAINS (Ghana Agricultural } \\
\text { Information Network System). }\end{array}$ & Ghana & http:// www.gains.org.gh/ \\
\hline $\begin{array}{l}\text { Mapronet (Market Access Promotion } \\
\text { Network). }\end{array}$ & Ghana & $\begin{array}{c}\text { http:/ / www.iicd.org/ projects/ ghana- } \\
\text { mapronet/ view }\end{array}$ \\
\hline Agri-ProFocus & Kenya & http:// apf-kenya.ning.com/ \\
\hline $\begin{array}{l}\text { SIMA (Mozambique Agricultural } \\
\text { Marketing Information System). }\end{array}$ & Mozambique & http:// www sima.minag.org.mz/ \\
\hline Manobi & Senegal & http:/ / www.manobi.sn/ sites/sn/ \\
\hline Manobi & South Africa & http:// www.manobi.sn/ sites/ za/ \\
\hline $\begin{array}{c}\text { Agricultural Marketing Information } \\
\text { System }\end{array}$ & South Africa & http:// www.manobi.sn/ sites/ za/ \\
\hline Farmers needs & Nigeria & http:/ / farmersneeds.iita.org/ index.htm \\
\hline Agri-ProFocus & Uganda & http:/ / apf-uganda.ning.com/ \\
\hline $\begin{array}{l}\text { CELAC (Collecting and Exchange of } \\
\text { Local Agricultural Content }\end{array}$ & Uganda & http:// www.celac.or.ug/ \\
\hline InfoTrade & Uganda & http:// www.infotradeuganda.com/ \\
\hline Mistowa & West African Countries & http:// www.mistowa.org/ en/ index.php \\
\hline $\begin{array}{l}\text { Jamaica Agricultural Market } \\
\text { Information System }\end{array}$ & Jamaica & $\begin{array}{c}\text { http:/ / www.ja- } \\
\text { mis.com/ CompanionSite/ home.aspx }\end{array}$ \\
\hline $\begin{array}{l}\text { West-African Market Information } \\
\text { System Network (WAMIS-NET) }\end{array}$ & West African Countries & http:/ / www.resimao.org/ html/ en \\
\hline $\begin{array}{l}\text { Zambia National Farmers Union } \\
\text { (ZNFU) Commodity Prices. }\end{array}$ & Zambia & http:// www.farmprices.co.zm/ \\
\hline $\begin{array}{l}\text { Cambodia Crop Production and } \\
\text { Marketing Project (CCPMP) }\end{array}$ & Cambodia & https:// ccpmp.pbworks.com/ w/ page/ \\
\hline e-Choupal & India & http:// www.echoupal.com/ \\
\hline AgriWatch & India & http:/ / www .agriwatch.com/ \\
\hline Agmarknet & India & http:/ / agmarknet.nic.in/ \\
\hline Kalimati & Nepal & http:/ / www kalimatimarket.com/ \\
\hline
\end{tabular}

Table 2: List of Some ICT Market Information Sources in Developing Countries Source: MMD4D, (2008)

\begin{tabular}{|c|c|}
\hline Organisations & Sources/ websites \\
\hline ASEAN (Association of Southeast Asian Nations) & $\mathrm{http} / /$ www.aseansec.org/ \\
\hline SAARC (South Asia Association for Regional Cooperation) & $\mathrm{http}: / /$ www.saarc-sec.org/ \\
\hline APAARI (Asia-Pacific Association of Agricultural Research Institutions) & $\mathrm{http://www.apaari.org/}$ \\
\hline FAO (Food and Agricultural Organisation of the United Nations) & $\mathrm{http} / /$ www.fao.org/ \\
\hline InfoDev (Information for development programme) & $\mathrm{www}$.infodev.org \\
\hline AARINENA (Association of Agricultural Research Institutions in the North- \\
East and North Africa) & $\mathrm{http://} \mathrm{www.aarinena.org/}$ \\
\hline APAN(Asia-Pacific Advanced Network) & $\mathrm{http://} \mathrm{www.apan.net/}$ \\
\hline APHCA (Animal Production and Health Commission for Asia and the Pacific) & $\mathrm{http://www.aphca.org/}$ \\
\hline ICAR (Indian Council of Agricultural Research) & $\mathrm{http} / /$ www.icar.org.in/ \\
\hline
\end{tabular}




\begin{tabular}{|c|c|}
\hline Organisations & Sources/ websites \\
\hline CGIAR (Consultative Group on International Agricultural Research) & $\mathrm{http://www.cgiar.org/}$ \\
\hline ISNAR (International Service for National Agricultural Research) & $\mathrm{http://www.isnar.cgiar.org/}$ \\
\hline IFPRI (International Food Policy Research Institute) & $\mathrm{http://www.ifpri.org/}$ \\
\hline CIAT (International Centre for Tropical Agriculture) & $\begin{array}{c}\mathrm{http} / / \text { www.ciat.cgiar.org/ Pag } \\
\text { inas/ index.aspx }\end{array}$ \\
\hline ICRAF (World Agro-Forestry Centre) & $\mathrm{http} / /$ www.worldagroforestr \\
& ycentre.org/ \\
\hline ICRSAT (International Crops Research Institute for Semi-Arid Tropics) & $\mathrm{http://} \mathrm{www.icrisat.org/}$ \\
\hline ECTAD (Eastern Caribbean Agricultural Trading and Development & $\begin{array}{c}\text { http:// the-eastern-caribbean- } \\
\text { trading.tradenote.net/ }\end{array}$ \\
\hline Association) & www.mardi.my \\
\hline
\end{tabular}

Table 3: Some Organisations in Developing Countries in Support of ICT-Enabled

Agricultural Information Systems

Source: Adapted from Singh, (2006)

\section{ICTs and Information Needs in Agriculture}

In any developmental or technological programme, people and their context probably determine the implementation of the innovations (Arunachalam, 2002), therefore the main aim of application of ICT in agriculture is to meet the information need of farmers (Dhaka and Chayal, 2010). Many researchers in their studies have identified some of the ICT needs of farmers in developing countries and these needs depend on the individuals involved and the country. This section identifies the information needs in agriculture in developing countries.

According to Steinen et al. (2007) the farmers need ICTs for:

- Enhancement of agricultural production: This is achieved through increasing agricultural productivity, efficiency and sustainability. Agricultural activity involves a lot of risks and uncertainties such as poor soils, drought, erosion, and diseases and pests. The provision of timely information will help in the reduction of the risks thereby improving productivity.

- Improving market access: Farmers need market information on prices for products, inputs and consumer trends in order to improve their livelihoods. Using ICTs, such information can be collected and stored and published on websites, or can be broadcast through rural radio, TV or mobile telephony.

- Empowerment and capacity building: Farmer organisations and communities through the use of ICTs can strengthen their capacities and abilities hence they will be in a better position to represent their constituencies when bargaining on input and output prices and infrastructure projects. ICTs enable farmers to interact with other stakeholders thereby reducing social isolation. It opens up new opportunities regional and globally (Steinen et al., 2007).

Generally, in Africa, according to the Forum for Agricultural Research in Africa (FARA, 2004), the information needs of farmers include: market information prices, weather forecasts, information on transport facilities and storage facilities, information on animal and crop diseases and fertilizers. The main information needs of the traders in Lira, Uganda according to Kleih et al. (2004) include market prices, demand and supply. The traders also indicated the need for information on availability and conditions of credit, taxation and other local government information and information on the cost and availability of processing equipment and crop insurance.

Moreover, the study done by Dhaka and Chayal (2010) states that in India, weather information, production practices, input price, plant protection measurement, farm produce price, value addition, livestock management practices and risk management are the information needs of farmers which are mainly provided by agricultural extension services using ICTs.

In addition, the research done in Bangladesh by Bidit (2009) revealed that the farmers' needs include: the prices and sources of the fertilizers, information about pests, crop diseases and cultivation methods, and output price information. Furthermore, in Nigeria, according to Adomi et al. (2003), the information needs of farmers include information on credit/ loan availability (82.2\%), improved methods of farming $(79.5 \%)$ information on availability and use of fertilizer (72.6\%), where to get agricultural implements/ machinery (72.6\%), pest and disease management (67.1\%), availability of improved seeds for cultivation $(54.8 \%)$, where to store the produce $(45.2 \%)$ and where to sell farm products (39.7\%). These information needs of farmers in Nigeria show that there are still many subsistence farmers who are still struggling with credit facilities and production leaving the commercial aspect which is marketing of agricultural produce.

According to AgREN, (2000), the most pressing information requirement of farmers in Kenya is information on technical details of farming such as how to manage late blight in potatoes, housing and management of their livestock, the most appropriate varieties for a given location, where to get improved and certified seed and the rate of applying chemicals.

According to IFPRI (2010) study of the roles of libraries in supporting agricultural policy research in Nigeria using focus group discussions with library staff, faculty members and post graduates in some selected universities, revealed that the information needs of students, academics and researchers for agricultural development are; effective and functioning libraries, internet access for journals and conference proceedings, computer stations and constant electricity. Moreover, the study by Papzan and Yaghoubi (2008), revealed that the main information needs of agricultural faculty members in 
Iran are: seminar and symposium announcements, book presentations, lists of research journals, research papers published in journals, statistics about agricultural and animal products, and announcement of research projects.

ICT, by providing the needs of farmers, boosts agricultural development services. Some of the agricultural development services that can be provided in developing using ICT, according to AgREN (2004), include:

Online services mainly for information gathering, consultation and monitoring, education and training, and processing and transaction;

The provision of early warning about diseases or pest problems, information pertaining rural development programmes, crop insurances, land records and post-harvest technologies;

Websites that are established by agricultural research institutes which will make up-to-date information available to extension workers and also facilitates feedback;

E-commerce for direct linkages between the stakeholders in agriculture such as the producers, processors, retailers, traders and suppliers;

Question and answer services where professions in the field respond to queries on specialised subjects for the development officials for greater efficiency in services and for overall agricultural development;

Up-to-date information such as weather forecasting, input suppliers, market information, and credit availability supplied to farmers as early as possible;

The enhancement of interaction among researchers, extension workers, farmers and other stakeholders in agriculture;

Creation of databases with particulars of the expert systems, resources of local villages and villagers, specific information of development site;

Enhance the efficiency and productivity of cooperative societies through the recent database technology and computer communication network.

The finding shows that the information needs of the farmers can be grouped according to the grouping proposed by Vodafone (2009) for grouping the information needs of farmers in India. According to Vodafone (2009), information needs of farmers through agricultural cycle can be categorised into know-how which includes what to plant and inputs such as seed varieties to use; market information such as the demand indicators, prices and logistical information; and the contextual information such as best agricultural practices and weather as shown in Figure 3. Table 4 shows the summary of the farmers needs using the agricultural cycle.

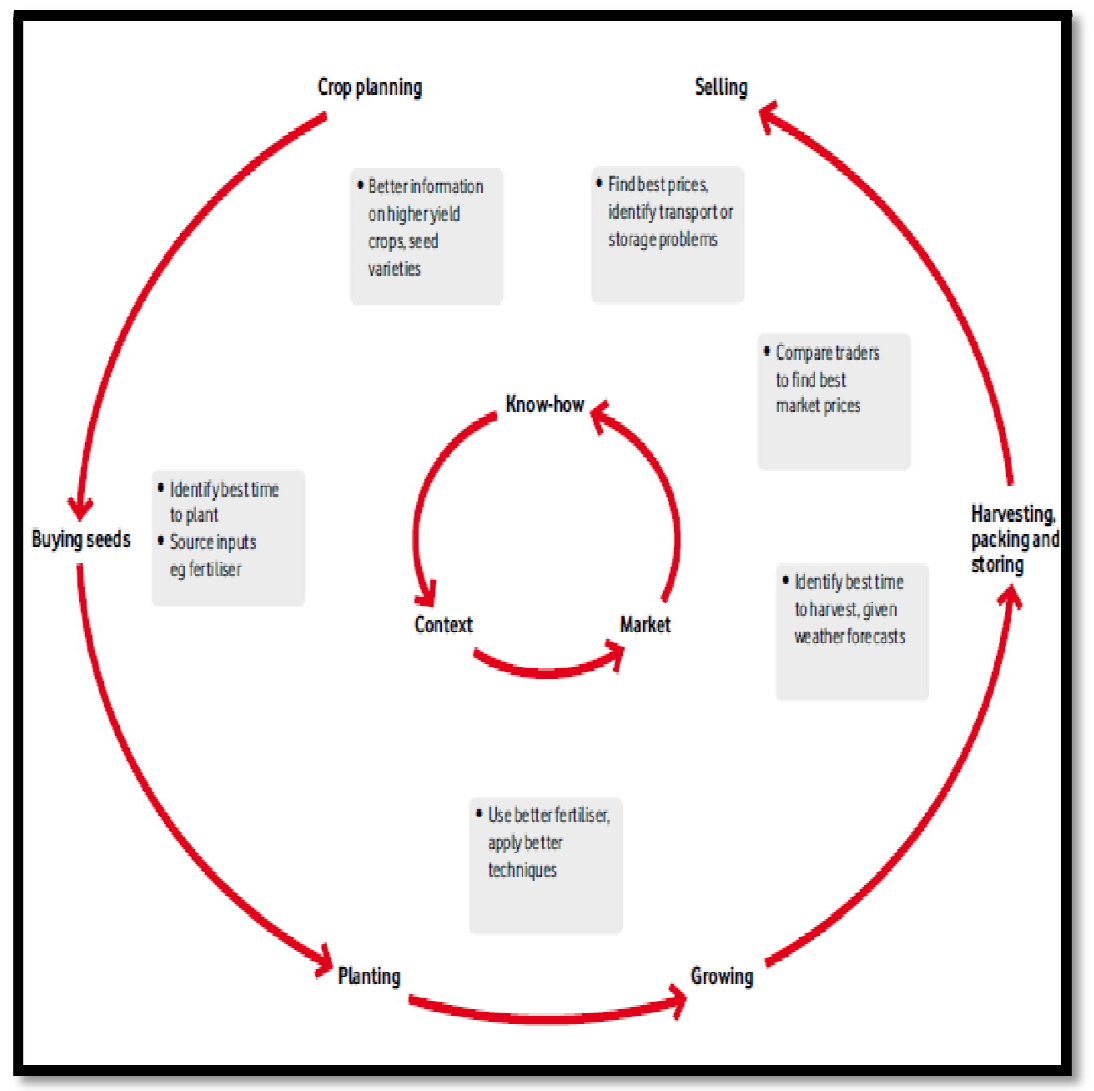

Figure 3: Information Needs through the Agricultural Cycle Source: Vodafone, (2009) 


\begin{tabular}{|c|c|c|c|c|}
\hline Know-How & $\begin{array}{c}\text { Marketing } \\
\text { Information }\end{array}$ & Contextual Information & Country & $\begin{array}{c}\text { Study } \\
\text { References }\end{array}$ \\
\hline $\begin{array}{l}\text { Information on } \\
\text { fertilizers }\end{array}$ & $\begin{array}{l}\text { Market prices, } \\
\text { information on } \\
\text { transport and } \\
\text { storage facilities }\end{array}$ & $\begin{array}{c}\text { Weather forecasts, } \\
\text { information on animal and } \\
\text { crop diseases }\end{array}$ & African countries & FARA, (2004). \\
\hline None & $\begin{array}{l}\text { Farm produce price, } \\
\text { input prices, Value } \\
\text { addition }\end{array}$ & $\begin{array}{l}\text { Weather information, } \\
\text { production practices, plant } \\
\text { protection measurements, } \\
\text { risk management and } \\
\text { livestock management } \\
\text { practices }\end{array}$ & India & $\begin{array}{c}\text { Dhaka and } \\
\text { Chayal, (2010). }\end{array}$ \\
\hline $\begin{array}{l}\text { Sources of fertilizer } \\
\text { and cultivation } \\
\text { methods. }\end{array}$ & $\begin{array}{l}\text { Prices of fertilizer, } \\
\text { output price } \\
\text { information }\end{array}$ & $\begin{array}{l}\text { Management of crop pests } \\
\text { and diseases }\end{array}$ & Bangladesh & Bidit (2009). \\
\hline $\begin{array}{c}\text { Availability of } \\
\text { improved seeds, } \\
\text { where to get } \\
\text { agricultural } \\
\text { implements/ } \\
\text { machinery, } \\
\text { Availability of loan } \\
\text { and credit } \\
\text { availability, } \\
\text { information on } \\
\text { availability and use } \\
\text { of fertilizer }\end{array}$ & $\begin{array}{l}\text { Where to store and } \\
\text { sell the products }\end{array}$ & $\begin{array}{l}\text { Information on improved } \\
\text { methods of farming, } \\
\text { information on pest and } \\
\text { disease management }\end{array}$ & Nigeria & $\begin{array}{l}\text { Adomi et al. } \\
\text { (2003). }\end{array}$ \\
\hline $\begin{array}{l}\text { Most appropriate } \\
\text { varieties of potatoes, } \\
\text { where to get } \\
\text { certified seed and } \\
\text { rate of applying } \\
\text { chemicals. }\end{array}$ & & $\begin{array}{l}\text { How to manage late blight in } \\
\text { potatoes, housing and } \\
\text { management of livestock }\end{array}$ & Kenya & AgREN, (2003). \\
\hline
\end{tabular}

Table 4: Summary of the Farmers Needs Using the Agricultural Cycle

However, all the information needs identified including the needs of agricultural students and researchers are in accordance with the agricultural development services that according to AgREN (2004) can be provided by ICTs in developing countries.

\section{References}

i. Adomi, E., Ogbomo, M. and Inoni, O. (2003). Gender factor in crop farmers' access to agricultural information in rural areas of Delta State, Nigeria. Library Review, Volume 52, Number 8, Pages 388-393.

ii. AFRRI (2009) (African Farm Radio Research Initiative) The effect of Participatory Radio Campaigns on Agricultural Improvement Uptake: A preliminary Case Study Assessment. Farm Radio International. [Online] Available at: http:/ / www.farmradio.org/ english/ partners/ afrri/ casestudy-report.pdf Accessed on 3/ 5/ 2011.

iii. AgREN, (2000). Agricultural Knowledge and Information Systems in Kenya- implications for technology dissemination and development. ODI, Agricultural Research and Extension Network Paper Number 107, 20 Pages.

iv. AgREN (2004). Information and Communication Technology in Agricultural Development: A comparative analysis of three projects from India. ODI, Agricultural Research and Extension Network Paper Number, 135, 20 Pages.

v. Arunachalam, S. (2002). Reaching the unreached: How can we use information and communication technologies to empower the rural poor in the developing world through enhanced access to relevant information. Journal of Information Science, Volume 28, Issue 6, Pages 513-522.

vi. Bidit, L. (2009). The use and appropriation of the mobile telephony technologies by the rural Bangladeshi farmers. American International University-Bangladesh (AIUB) Bus Econs Working Paper Series, Number 2009-02.

vii. Dhaka, B. and Chayal, K. (2010). Farmers' experience with ICTs on transfer of technology in changing agri-rural environment. Indian Research Journal of Extension Education,Volume 10, Issue 3, Pages 114-118, September, 2010.

viii. Ekoja, I. (2003). Farmer's access to agricultural information in Nigeria. Bulletin of the American Society for Information Science and Technology, Volume 29, Issue 6, Pages21-23.

ix. FAO (2000). Information and Communication Technologies for rural development and food security: Lessons from field experiences in developing countries. Sustainable Development Department (SD), Food and Agriculture Organisation of the United Nations. 
x. FARA (Forum for Agricultural Research in Africa) (2009). Inventory of Innovative Farmer Advisory Services using ICTs. [eds: Gakuru, M., Winters, K. and Stepman, F.). [Online] Available at: http://www.faraafrica.org/ media/ uploads/ File/ NSF2/ RAILS/ Innovative_Farmer_Advisory_Systems.pdf. $\quad$ Accessed on $12 / 11 / 2010$.

xi. Ha, L., Okigbo, R. and Igboaka, P. (2008). Knowledge creation and dissemination in Sub-Saharan Africa. Management Decision, Volume 46, Number 3, Pages 392-405.

xii. IFPRI (International Food Policy Research Institute) (2010). Role of libraries in supporting agricultural policy research- evidence from selected university and research institute libraries in Nigeria. NSSP Background Paper, Number 14. International Food Policy Research Institute, 2033 K Street, NW Washington, DC 20006-1002, USA.

xiii. IICD (International Institute for Communication and Development) (2006). ICTs for Agricultural Livelihoods: Impacts and Lessons Learned from IICD Supported Activities. Raamweg 5, Hague, Netherlands.

xiv. Kalusopa, T. (2005). The challenges of utilizing Information Communication Technologies (ICTs) for the smallscale farmers in Zambia. Library Hi Tech 23, Pages 414-424.

xv. Kari, H. (2007). Availability and accessibility of ICT in the rural communities of Nigeria. The Electronic Library, Volume 25, Number 3, Pages 363-372

xvi. Kleih, U., Okoboi, G., and Janowski, M. (2004). Farmers and traders' sources of market information in Lira District. NARO Conference, 1-4 September 2004, Paper 57-5, 25 Pages. [Online] Available at: http:/ / www.dfid.gov.uk/ r4d/ PDF/ Outputs/ R8250s.pdf Accessed on 23/ 3/ 2011.

xvii. MMD4D, (2008). ICT market information Projects. [Online] Available at: http:// mmd4d.wordpress.com/ict4dmarketplace-projects/ \#International Food Price Sources. Accessed on 2/ 4/ 2011.

xviii. Mwakaje, A. (2010). Information and Communication Technology for rural farmers market access in Tanzania. Journal of Information Technology Impact, Volume 10, number 2, pages 111-128, 2010.

xix. Papzan, A. and Yaghoubi, J. (2008). Identifying electronic information needs of agricultural faculty members. IAALD AFITA WCCA 2008. World Conference on Agricultural Information and IT.

xx. Singh, S. (2006). Selected success stories on Agricultural Information Systems. Paper for Asia-Pacific Association of Agricultural Research Institutions (APAARI). FAO Regional Office for Asia and the Pacific, 39 Phra Atit Road, Bangkok 10200, Thailand.

xxi. Stienen, J., Bruinsma, W. and Neuman, F. (2007). How ICT can make a difference in agricultural livelihoods. International Institute for Communication and Development (IICD). The Commonwealth Ministers Reference Book-2007.

xxii. USAID, (2003). Future directions in agriculture and Information and Communication Technologies (ICTs) at USAID. Background Paper Prepared for USAID, Economic Growth, Agriculture, and Trade, Agriculture and Food Security by Winrock International, Version 4-14, 85 pages.

xxiii. Vodafone (2009). India: The Impact of Mobile Phones. Moving the debate forward. The Policy Paper Series, Number 9, January, 2009.

xxiv. Weiss, A., Van Crowder, L. and Bernard, M. (2000). Communicating agrometerological information to farming communities. Agriculture and Forest Meterology, Volume 103, Pages 185-196. 